\title{
FREEZING CONTROLS: THE EFFECTS OF AN UNLICENSED TRANSACTION
}

\author{
RAOUL BERGER and BORIS I. BITTKER
}

On April 10, 1940-forty-eight hours after Germany began her invasion of Denmark and Norway-the United States prohibited a wide range of transactions in the assets within this country owned by the Governments of the invaded countries and by their nationals. ${ }^{1}$ By depriving the Axis of access to these funds and securities, Executive Order No. 8389 forestalled their use for subversive activities in this country or for commercial dealings with European neutrals, at the same time protecting the alien owners and their American creditors against forced transfers of the properties. ${ }^{2}$ In sticcessive months freezing controls were extended to the assets of the Low Countries and of France ${ }^{3}$; the coverage of the Order continued to match the march of events until, with the President's declaration of an unlimited na-

1. Exec. Order No. 8389, 5 FED. REG. 1400 (1940). For present purposes, the more significant transactions prohibited by this Order, as amended, are transfers of credit between banks, payments by or to banks, transactions in foreign exchange, and transfers of evidences of indebtedness or of ownership of property, provided that the transaction either (1) is by or on behalf of a foreign country designated in the Order or a national thereof, or (2) involves property in which a designated foreign country or a national thereof has had any interest since the effective date of the Order. The principal documents relating to the freezing program may be found in Documents Pertaining to Foreign Funds ConTROL (U. S. Dep't Treas. 1945) and supplements thereto (hereinafter TrEAsuRY DocUMENTs). For general discussion, see Administration of the. Wartime Financial and Property Controls of the United States Government (U. S. Dep't Treas. 1942) (hereinafter Treasury ConTRoLs); Reeves, The Contral of Foreign Funds by the United States Treasury, 11 LAW AND CoNTEMP. PROB. 17 (1945). No views are herein expressed as to the range of the transactions to which the Order applies.

The underlying authority for the foreign funds control program is $\S 5(\mathrm{~b})$ of the Trading With The Enemy Act, as amended. [55 STAт. 839 (1941), 50 U. S. C. ApP. \$616 (Supp. 1946)]. The program was launched under the aegis of $\$ 5(\mathrm{~b})$ as it existed after its amendment by the Emergency Bank Legislation of 1933 [48 STAT. 1 (1933), 50 U. S. C. APP. \$ 5(b) (1940)], but Executive Order No. 8389 and the regulations issued thereunder were approved and confirmed by the Joint Resolution of May 7, 1940, 54 STAT. 179 (1940). A similar ratification of existing regulations was included in the First War Powers Act [55 Stat. 840 (1941), 50 U. S. C. App. \$617 (Supp. 1946)], which again amended $\S 5(b)$. The program may be regarded, therefore, as possessing from its inception the sanction of $\$ 5(\mathrm{~b})$ as presently constituted. For the program's constitutionality, see United States v. Von Clemm, 136 F. 2d 968 (C. C. A. 2d 1943), cert. denied, 320 U. S. 769 (1943); McNulty, Constifutionality of Alien Property Controls, 11 LAW AND CONTEMP. PROB. 135, 136-39' (1945).

2. In the Brief for United States as amicus curiae, pp. 5-14, Commission for Polish Relief v. Banca Nationala a Rumaniei, 288 N. Y. 332, 43 N. E. $2 d 345$ (1942), the purposes of the controls are summarized as follows:

"1. Protecting property of persons in occupied countries . . . 2. Preventing the Axis, now our enemy, from acquiring any benefit from these blocked assets . . . 3. Facilitating the use of blocked assets in the United Nations war effort and protecting American banks and business institutions ....4. Protecting American creditors. ... 5. Foreign relations, including post-war negotiations and settlements."

For the evolution of these purposes, see Littauer, The Unfreezing of Foreign Funds, 45 Columbia Law Rev. 132, 134-137 (1945).

3. The Netherlands, Belgium, and Luxembourg: Exec. Order No. 8405, 5 FED. Reg. 1677 (1940) ; France: Exec. Order No. 8446, 5 id. at 2279. 
tional emergency on June 14, 1941, the controls were extended to the assets of Germany, Italy, and every other European country not previously embraced. ${ }^{4}$ Eminently successful in achieving their intended purposes in wartime, ${ }^{5}$ the controls imposed by Executive Order No. 8389 are now in the process of liquidation. ${ }^{6}$ It is not surprising, since the prohibitions of the Order called an unaccustomed halt to free trade in eight and one half billion dollars' worth of assets, ${ }^{7}$ that "defrosting" has accentuated a number of old legal problems and has brought with it a myriad of new ones.

Not the least perplexing of these issues is one which has long hovered in the background: what are the legal consequences of an attempted transfer of frozen assets in violation of the Order? If a custodian of a blocked account is confronted with a post-defrosting assignment of blocked property, when he knows of the existence of (or has been requested to honor) an unlicensed pre-defrosting assignment, can he safely ignore the unlicensed document and honor the post-defrosting instrument, particularly when he must take into account the possibility that eventually the freezing controls will be entirely revoked? In administering the return provisions recently added by Congress to the Trading with the Enemy Act, ${ }^{8}$ what weight should the Office of Alien Property ${ }^{9}$ give to claims based upon unlicensed transactions? What is the effect of an unlicensed assignment or attachment of frozen funds upon an order of the Office of Alien Property vesting the funds, ${ }^{10}$ in view of the Government's

4. Exec. Order No. 8785, 6 FED. REg. 2897 (1941).

5. We have official Japanese testimony for the paralyzing effectiveness of the program. Freezing made it "impossible for Nippon to continue trade with the nations employing the settlement of accounts system based on the American dollar," and it isolated "Nippon from the supply of essential wartime materials and frustrated Nippon's design to establish the Greater East Asia Co-Prosperity Sphere." The American-British Challenge DIRECTEd AGAINST NIPPON, 79, 81 (official pamphlet published by the Japanese Government, 1943).

See also the German decree promulgated in Holland requiring the reporting of all securities not bearing a tax stamp, to counter the Treasury program. TREASURY ConTrols, supra note 1 , at 22 .

6. The controls were relaxed for future transactions by General License No. 94, issued Dec. 7, 1945, [10 FED. REG. 14814 (1945)], and the release of property previously blocked was authorized under certain circumstances by General License No. 95, issued Dec. 29, 1945. [10 FED. REG. 15414 (1945)]. The latter provides for the release of blocked property upon certification by the designated agent of a specified foreign country (the list of which, at present writing, included the liberated European countries plus Switzerland and Liechtenstein) that no non-specified country or national thereof has had any interest in the property at any time since the effective date of the Order. The procedure is more fully described by Littauer, Defrosting of Foreign Funds, 1 WORLD Trade L. J. 163 (1946); see also Littauer, sipra note 2.

7. See Hearings before Committee on Appropriations on $H . R .1000,79$ th Cong., 1st Sess. (1946).

8. Pub. L. No. 322, 79th Cong., 2d Sess., (March 8, 1946).

9. The functions formerly performed by the Office of Alien Property Custodian are now exercised by the Office of Alien Property, in the Department of Justice.

10. Exec. Order No. 9095 [7 FED. REG. 1971 (1942)], as amended by Exec. Order No. 9567 [10 id. 6917 (1945)] authorizes the vesting of German and Japanese-owned funds and securities. 
practice of leaving American interests in foreign-owned property inviolate ${ }^{11}$ Answers to these and many other questions cannot be given without an analysis, long overdue, of the aims and methods of freezing controls with particular emphasis on the legal status of an unlicensed transaction.

The prohibitions of Section 1 of the Executive Order have the approval and implement the purpose of Congress. ${ }^{12}$ That purpose was

"preventing change of title of the property here in the United States by conquest, or by any other forcible or violent means."

It is familiar learning that a contract made in violation of a valid prohibition designed for police or regulatory purposes is void, ${ }^{14}$ even when not expressly declared void. ${ }^{15}$ By Paragraph (1) of General Ruling No. 12,10 said in the accompanying Press Release No. $34^{17}$ to be only declaratory of

11. The interests of American citizens in foreign-owned property are either left untouched by the Custodian's vesting order, as when he seizes only the "right, title and interest" of the foreign national, or, if displaced, as by the vesting of a described "res," may be reasserted in a proceeding under $\$ 9(\mathrm{a})$ of the Trading With The Enemy Act. Certain persons, including aliens, may assert their rights under $\$ 32$. Pub. L. No. 322, 79th Cong., 2d Sess., (March 8, 1946).

12. See note 1 sipra.

13. 86 Cong. REC. 5007 (1940) (Senator Connally). Senator Wagner pointed out that under the Act of 1917 "no transfers could be made by citizens of another country owning property here without a license from the Government." (Id. at 5008). Senator Glass said "The plain intent of the joint resolution is to prevent Germany from appropriating the property, now in the United States belonging to the two nations she is now overwhelming." (Id. at 5176). Senator Connally emphasized that it required the president's "permission to transfer the title." (Id. at 5179).

In reporting the amendment to $\$ 5(\mathrm{~b})$ of the Trading With The Enemy Act, subsequently embodied in Title III of the First War Powers Act [55 STAT. 839 (1941), 50 U. S. C. ApP. \$616 (Supp, 1946)] the Senate Judiciary Committee said: "The existing foreign property control regulations (popularly known as 'freezing control') have permitted the Government to prevent and regulate transactions relating to foreign property. $\therefore$ " SEN. Rep. No. 911, 77th Cong., 1st Sess. 2 (1941). See also H. R. Rep. No. 1507, 77 th Cong., 1st Sess. 3 (1941).

14. Ewert v. Bluejacket, 259 U. S. 129 (1922) ; Hartman v. Lubar, 133 F.2d 44 (App. D. C. 1942); Suspine v. Compania Transatlantica Centroamericana, 37 F. Supp. 268, (S. D. N. Y. 1941); United States v. Dake, 42 F. Supp. 833 (N. D. N. Y. 1941) (violation of administrative order). The law of New York is not to the contrary. Adler v. Zimmerman, 233 N. Y. 431,135 N. E. 840 (1922). Compare John E. Rosasco Creameries, Inc. v. Cohen, 276 N. Y. 274,11 N. E.2d 908 (1937), with Flegenheimer v. Brogan, 284 N. Y. 268,30 N. E.2d 591 (1940).

15. Barlett v.' Vinor, Carth. 251, 90 Eng. Rep. 750 (1693) (Lord Holt); The Pioneer, 19 Fed. Cas. 711, No. 11,177 (D. Ore. 1864); cf. Lakos v. Saliaris, 116 F.2d 440 (C. C. A. 4th 1940).

16. 7 FED. REG. 2991 (1942). In addition to drawing on $\$ 12$ of Exec. Order No. 8389 , which authorizes the Secretary of the Treasury "to prescribe ... regulations . to carry out the purposes of this Order" the Treasury could rely on that portion of $\S 5(b)$ of the Trading With The Enemy Act which authorizes the president or his delegate to ". . nullify, void ... any ... transfer ... or transactions involving, any property in which any foreign country or a national thereof has any interest. ..."

17. TREAsury Docunents, supra note 1 , at 100 . A few problems as to the scope of Genera1 Ruling No. 12 may here be noted. Since the Ruling applies by its terms only to property in "blocked accounts" (as defined by General Ruling No. 4, [5 FED. REG. 2133 (1940), 6 id. 2583, 3350 (1941)], it has been suggested that the Treasury's policy with respect to other categories of frozen assets may be less drastic. (Littauer, supra note 2 , at 
existing law, the Treasury declared that unlicensed transactions are "null and void," or as the Press Release puts it "void and unenforceable."

The stringency of these provisions was not unintended: a basic purpose of the Order was to prevent the Axis from using the American assets of invaded or overrun countries in order to obtain supplies from neutral countries; to achieve this result, it was imperative to blast any hope which neutral speculators might entertain of waiting for ultimate lifting of the freezing controls and of then realizing on transferred assets. ${ }^{18}$ Authority supporting

140). But the Ruling purports to be declaratory of the impact of the Order on unauthorized transactions in blocked assets. (Press Release No. 34, TREAsury DOCUMENTs, supra note 1, at 100 ). Since the Order speaks only of prohibited transactions, without regard to whether or not the property involved is in a blocked account, it is arguable that the declaratory interpretation embodied in General Ruling No. 12, though expressly applicable only to blocked accounts, equally illuminates the effect of the Order on other categories of frozen property, or on any property in which a foreigu national has an interest.

Littauer likewise suggests that the declaration of nullity contained in General Ruling No. 12 exceeds the scope of the President's delegation of authority to the Treasury Department, since the Order speaks only of persons within the United States, while the Ruling condemns transfers wherever attempted. But he notes that the Ruling was issued "By direction of the President," which would seem to cure any defect in the prior delegation. There is no doubt that the Congress intended to reach transfers outside the United States, for the debates are replete with references to transfers under pressure of the invaders. [86 CoNG. REc. 5006-08, 5168-83 (1940)]. Looting could only be reached if transfers in the looted countries were struck down. Nullification of improper transfers is in harmony with various declarations of the United Nations, which are incompatible with endowing tainted transfers with any legal consequences. Thus, on Jan. 5, 1943, a joint declaration by the United States and seventeen other United Nations stated that they. "reserve all their rights to declare invalid any transfers of, or dealings with, property, rights and interests of any description whatsoever which are, or have been situated in the territories which have come under the occupation or control, direct or indirect, of the governments with which they are at war or which belong or have belonged to persons, including juridical persons, resident in such territories. This warning applies whether such transfers or dealings have taken the form of open looting or plunder, or of transactions apparently legal in form, even when they purport to be yoluntarily effected." (TREASURY DocumENrs, supra note 1, at 11.) A declaration of similar terlor respecting gold purchases was made on February 22, 1944, when the United States (and, in similar pronouncements, the United Kingdom and the Soviet Union) announced that "[I]t does not and will not recognize the transference of title to the looted gold which the Axis at any time holds or has disposed of in world markets." (TREASURY DocUMENTS, sipra note 1, at 11). Further evidence of United Nations policy was given by Resolution No. VI of the United Nations Monetary and Financial Conference at Bretton Woods, July, 1944, approving steps already taken to search out looted property and restore it to its lawful owners and recommending immediate measures to prevent the transfer of property belonging to persons in occupied countries. TREASURY DOCUMENTS, supra note 1 , at 12.

18. Treasury Department Press Release No. 34 (TREAsury Docunenrs, supra note 1, at 100), which accompanied the issuance of General Ruling No. 12, explained: "This neutral black market operation would be designed to give the Axis immediate returns on blocked assets even though the Axis could not get such assets out from under our freezing regulations. In this case the assets would be assigned or otherwise transferred to neutral speculators at heavy discount in order that the Axis could obtain credit now to buy goods and services in neutral countries and thus assist the war effort. Of course some of these black market operations would be for the obvious purpose of lining the pockets of Axis officialdom as insurance against the day when the Axis is crushed. Neutral speculators would either hold such assignments with the intent of salvaging on them after the war or in the hope of being able to squeeze the blocked assets through the freezing control by one trick or another." See also Brief for United States in the Polish Relief case, supra note 2 , pp. $7-9$. 
the Treasury pronouncement in the very field of "freezing control" is furnished by Schrijver $v$. Sutherland, ${ }^{10}$ which held that a transfer (during World War I) in Europe to a Dutch partnership of German-owned shares in an American corporation was invalid under $\S 7(b)$ of the Trading with the Enemy Act. If no more were involved, it would be, as Chief Justice Taney remarked, a gross error

"to say that a contract, forbidden by an Act of Congress, or against its policy, was not fraudulent and void, and that it might be enforced in a court of Justice . . . .".

But before concluding that unlicensed transactions may be regarded as a complete nullity, one must take account of the administrative practice under the Order. In permitting a license to be applied for "before, during or after" a transfer, ${ }^{21}$ the Treasury Department countenanced unlicensed transactions in blocked property, though still affirming that they would be "void and unenforceable" unless and until a license was issued. ${ }^{22}$ Moreover, in a curious ruling which will be examined in detail later, the Treasury provided that, in the event of litigation, any transfer affected by the Order shall

"be valid and enforceable for the purpose of determining for the parties to the action or proceeding the rights and liabilities therein litigated ...."

And despite the fact that the Treasury had stamped unlicensed transactions as "unenforceable," it suggested to parties that

"they adjudicate such [disputed] claims before applying for a license to permit the transfer of funds."

It should occasion no surprise that courts which have grappled with these issues have been perplexed by the Treasury's apparently conflicting rulings that an unlicensed transfer is "void and unenforceable" but must nevertheless be regarded as "valid and enforceable" for the purposes of litigation. Although the New York Court of Appeals, which has decided the two most important cases in this field, got off to a good start in the Polish Relief case, ${ }^{25}$ it subsequently lost its footing and established principles in Singer v. Yoko-

19. 19 F.2d 688 (App. D. C. 1927).

20. Walworth v. Kneeland, 15 How. 348,353 (U. S. 1853).

21. Paragraph (3), General Ruling No. 12, 7 FED. REG. 2991 (1942).

22. Press Release No. 34, supra note 18.

23. Paragraph (4), General Ruling No. 12, supra note 21. infra.

24. Brief for United States in the Polish Relief case, supra note 2, p. 14; see pp. 410-11,

25. Commission for Polish Relief, Ltd. v. Banca Nationala a Rumaniei, 288 N. X. 332, 43 N. E.2d 345 (1942); 11 GEo. WASH. L. REv. 116 (1942); 37 ILI. L. REv. 270 (1942); 91 U. OF PA. L. REv. 260 (1942). See also Reeves, supra note 1, at 47-49; Reeves, Policies of the United States Treasury As Applied to Blocked Funds in Litigation, 113 N. Y. L. J. 2180, 2200 (1945); comments in American Banker, Oct. 23, 1942, p. 3, col. 2, and letter of Mr. Randolph E. Paul, General Counsel of the Treasury Department, in response thereto. Id., Dec. 11, 1942, p. 3, col. 2. 
hama Specie Bank ${ }^{26}$ which, if left unchallenged, go far to sap the effectiveness of the war-time controls. Its holdings will be analyzed in greater detail below, but it may be noted here that the earlier Polish Relief case recognized that:

"The words [in the Executive Order] of the Chief Executive of the nation must be taken to have deprived the defendant of power to transfer any interest in these blocked accounts except through the medium of assignment subject to a releasing of the credit by the Secretary of the Treasury."

In contrast, the same court said in Singer v. Yokohama Specie Bank that certain unlicensed dealings between the Yokohama Specie Bank and the Standard Vacuum Oil Company

\footnotetext{
"served to create an enforcible legal obligation by the New York Agency [of the Yokohama Specie Bank] to make such payment. . . . The fact that Federal regulations governing transactions in foreigu exchange prevent the payment to Standard until a license under Executive Order No. 8389, as amended, is procured does not make conditional the obligation of the New York Agency to pay."
}

If the court meant to hold that an unlicensed transaction could create a legal obligation, the enforceability of which was only postponed by the freezing restrictions, it seems to follow that ultimate suspension of the controls will result in reviving the transaction's enforceability. Such a consequence would thwart a major objective of the Order: to destroy any opportunity for neutral speculators to profit by dealing in blocked assets in the United States. Moreover, we believe that this result, which would frustrate the congressional purpose of "preventing the passage of title" to frozen assets, ${ }^{29}$ finds no real support in either the rulings or the administrative practice under the Order, notwithstanding occasional lapses in the Treasury position which lend superficial color to it. A preliminary analysis of the Polish Relief and Singer cases may furnish a background against which to examine the Treasury's rulings and practice under the Order.

\section{The Polish Relief and Singer Cases}

The Polish Relief case involved the question whether jurisdiction in rem over an absent defendant could be acquired by the levy of state court attachments against its blocked deposit accounts in several New York banks. ${ }^{30}$ The United States was not a party to the suit, but in its brief as amicus curiae before the New York Court of Appeals argued that:

26. 293 N. Y. 542,58 N. E.2d 726 (1944).

27. 288 N. Y. $332,337,43$ N. E.2d 345,347 (1942).

28. 293 N. Y. $542,549,550,58$ N. E.2d 726,728 (1944).

29. See note 13 supra.

30. The plaintiff had received no license, but none was required to commence an action. Brief for United States in the Polish Relief case, supra note 2, pp. 39-42. Payment from the blocked accounts, even to the sheriff, could not be made without Treasury authorization, however, as the court recognized. 
"An assignment by a national to $\mathrm{A}$ of the national's interest in a blocked account does not divest the national of any interest in the account and does not vest any interest in the account in A, unless and until such assignment is authorized by the Treasury Department.

"An attachment action against a national's blocked account is an attempt to obtain an unlicensed assignment of the national's interest in the blocked accountnothing more and nothing less.

"In this sense, the attachment action might be regarded as a levy upon the nationals (sic) contingent power (i.e., contingent upon Treasury authorization) to transfer all his interest in the blocked account to $A$; any judgment in the attachment action resulting in giving $A$ a contingent interest in the account equivalent to what he would have obtained by voluntary assignment."

The brief of the United States went on to express acquiescence in the levy of an attachment if, but only if, under New York law a valid attachment could be levied on such a "contingent power."32

A majority of the Court of Appeals, in upholding the attachments, apparently adopted the rationale advanced in the brief of the United States, and unequivocally repudiated the broad ground upon which the Supreme Court and Appellate Division had upheld the levies:

"As read by the Special Term the Executive Order leaves open the way to an 'assignment of the defendant's claims against the banks that would carry the title.' ... The Appellate Division likewise conceived of the Order as a command which 'operates exclusively in personam upon the banks.' We hold a different opinion in respect of this question.

"The Executive Order is a check upon trading with the enemy. Its prime pur- pose is to stop such uses of foreign property rights as might imperil national defense. The words of the Chief Executive of the nation must be taken to have deprived the defendant of power to transfer any interest in these blocked accounts except through the medium of assignment subject to a releasing of the credit by the Secretary of the Treasury."233

The majority went on to point out that the banks continued to owe debts to the defendant, notwithstanding the defendant's inability, resulting from the Order, to collect them. It concluded that the banks' liabilities were not transmuted into contingent obligations and that they continued to be attachable:

"For all we know, payment of the blocked accounts to the credit of this action can be permitted consistently with the purpose of the Order. ... The lien of an attachment is always hypothetical in some degree. A 'seizure subject to license' was, we think, sufficient for the purpose of jurisdiction in rem over the deposits in question."36

31. Id. at 50-52. The United States did not enter the case as amictis curiae until after the attachments had been upheld by the Supreme Court and Appellate Division; indeed, the Government's brief is dated April 21, 1942, while argument before the Court of Appeals was had on March 18, 1942.

32. Id. at 53 .

33. 288 N. Y. 332, 337, 43 N. E.2d 345, 347 (1942) (italics added).

34. Id. at 338,43 N. E.2d at 347 . 
The minority even more forcibly declared that

"No transfer of title in the absence of a license is permitted by the wording of the Executive Order, whether the transfer be by means of assignment or attachment."

But it inferred from this fact, as to which there was agreement, that the defendant's control over the accounts was too uncertain to be the subject of levy under New York law, saying that:

"What the plaintiff is seeking here is a res sufficiently illusory not to fall within the all-inclusive prohibition of the Executive Order and at the same time to be sufficiently substantial to afford a basis for jurisdiction. In my opimion such inconsistency seeks the impossible. Hence within the authorities no attachment is possible."”s

In sum, all judges of the Court of Appeals adopted the Treasury view that no transfer of blocked assets could be accomplished either by voluntary act or attachment, but the majority held that an attachment for jurisdictional purposes could be based upon a blocked national's contingent right to transfer when licensed.

In light of this unanimity respecting the impossibility of transferring any interest in blocked property without a Treasury license, the Court's subsequent unanimous decision in Singer v. Yokohama Specie Bank ${ }^{37}$ that an enforceable legal obligation was created by an unlicensed transaction in foreign exchange though payment of the obligation was inhibited came as a complete surprise. In the Singer case the plaintiff sought to enforce a claim arising out of the delivery on August 2\%, 1941, by the Yokohama office of the Standard Vacuum Oil Company to Yokohama Specie Bank, Ltd., in Japan of the yen equivalent of $\$ 557,561.25$ with instructions to pay the dollar amount to Standard in New York. Two days later, the Bank's New York Agency advised Standard that it had received such instructions and that the amount was available for payment to Standard upon procurement of a Treasury license. Two applications for such a license were denied by the Treasury Department. ${ }^{38}$ The Court of Appeals somewhat enigmatically stated that these dealings

"served to create an enforcible legal obligation by the New York Agency to make such payment .... . The fact that Federal regulations governing transactions in foreign exchange prevent the payment to Standard until a license under Executive Order No. 8389 , as amended, is procured does not make conditional the obligation of the New York Agency to pay. ${ }^{230}$

In a brief supporting a motion for reargument, the Government asked for clarification, pointing out that the apparent holding that unlicensed transac-

35. Id. at 339,43 N. E.2d at 348 .

36. Id, at 341,43 N. E.2d at 349 .

37. 293 N. Y. 542,58 N. E.2d 726 (1944).

38. Brief for United States as amicıus curiae, p. 6, Singer v. Yokohama Specie Bank;

293 N. Y. 542, 58 N. E.2d 726 (1944).

39. 293 N. Y. 542, 549, 550, 58'N. E.2d 726, 728 (1944). 
tions "gave rise to enforceable rights, subject only to control of payment" would "defeat in large measure the efficacy" of the freezing controls. ${ }^{40}$ The motion was denied. ${ }^{41}$

It may be thought, since the Singer case leaves the Treasury with control over payment, that the difference between the New York court and the Government is only one of semantics. But the Singer case appears to treat an unlicensed transfer of frozen funds as a delayed action instrument, and this could certainly encourage neutral speculators who took assignments of looted credits to hope that patience in outwaiting freezing controls will ultimately be rewarded. ${ }^{42}$ It also suggests that custodians of blocked accounts cannot honor post-defrosting assignments of such accounts, at least not if they know of the existence of earlier, though unlicensed, transfers. Then too, the protection of American creditors requires that the status quo of frozen assets be maintained so that creditors may proceed against the property of their debtors. Again, the vesting of blocked enemy accounts would be forestalled if unlicensed assignments are held to pass title to or create liens against such accounts.

To be sure, it is open to the Government to maintain the regulatory machinery of Executive Order No. 8389 permanently in force, and at some time this could be coupled with an announcement that applications for licenses to validate unlicensed transactions would no longer be entertained and that licenses should be regarded as irrevocably denied to all transfers theretofore not licensed. Thus unlicensed transactions would be rendered unenforceable in perpetuity, though even this statement might not completely dispel the clouds created by the Singer view of unlicensed transactions. And this device, clumsy at best, would be superfluous were it not for the Singer case's misinterpretation of the effects of an unlicensed transaction.

\section{InefFectiveness of Voluntary Unlicensed Transfers}

Although transactions in foreign-owned property were prohibited by the Executive Order under penalty of fine and imprisonment and although transfers of blocked accounts were expressly voided, the Treasury Department as a matter of administrative practice did not prosecute persons engaging in the

40. Brief for United States as amicus curiae in support of respondent's motion for reargument, p. 3, Singer v. Yokohama Specie Bank, 293 N. Y. 542,58 N. E.2d 726 (1944). Recently Leeds v. Guaranty Trust Co. [65 N. Y. S. 2d 431 (Sup. Ct. 1946)], cited the Singer case for the- proposition that Executive Order No. 8389 "interdicted solely payment and not ... the assignment of a claim ...." The Leeds case likewise relies on Reeves, supra-note 25. But Reeves stated "It is not the purpose of this article to take a position in regard to the correctness of interpretation of the Executive Order or the ultimate significance of any position so taken, either as expressed by the Courts or by the Treasury." Id. at 2200 .

41. 294 N. Y. 689,60 N. E.2d 842 (1945).

42. See note 18 supra. 
interdicted transactions. To the contrary, instead of requiring persons who wished to engage in a forbidden transaction to obtain advance approval, the Department uniformly not only countenanced but insisted upon the execution by the parties of the instruments of transfer prior to applying for a license. ${ }^{43}$ This practice was no doubt thought to be compelled by administrative exigencies; the Treasury Department was thereby relieved of the task of passing on hypothetical or contemplated transactions, ${ }^{44}$ while the national interest was adequately protected by the justifiable assumption (now threatened by the Singer case) that the transaction was totally ineffective to create or transfer any interest in the blocked property unless and until properly licensed.

At this juncture we can glance with profit at the closely analogous German experience with freezing control, because German jurists have given extended consideration to the effects of a prohibited transaction in the interval before it is licensed. Section 64(1) of the German Devisenrecht provides, roughly speaking, that a prohibited transaction is nichtig or void. Subsection (2), in striking resemblance to the Treasury practice, declares that "if the transaction is subsequently approved, it becomes effective from the time of its inception." ${ }^{45}$ It is not, therefore, an absolute nullity. Instead, German writers and jurists are agreed that, until licensed, a transaction is merely in a state of suspense; it is ineffective (schwebend unvirksam) ${ }^{46}$ and has no legal consequences. ${ }^{47}$ Juristically speaking, a contract is merely a relation to which the State lends its sanctions if the parties have complied with certain formal requirements, such as consideration, assent and the like. The State may impose the additional requirement that the parties obtain express State approval before the contractual relation will be given effect. 48 Just as we are accustomed to say that lacking the "consent" of both parties there is no contract, so we may conclude that there is no contract in the absence of the "consent" by the State. In fine, the unlicensed contract is not an incurable nullity; it is merely in a state of ineffective suspense until licensed.

43. Reeves, supra note 1 , at 45 ; Reeves, supra note 25 , at 2180 .

44. In the fiscal year 1944-45 the federal reserve banks and the Treasury Foreign Funds Control received 101,000 applications for licenses. United States SeC'y of Treas. AnNual REP. 1945, p. 206 (1946).

45. For text and summary history see Grese \& NIENANN, KoMrarentar zUM DEvisENGESETz 438 (ed. 1942). Subsection (2), which was added by an amendment, resolved the problem whether an absolutely void transaction can be cured. Cf. Peltzer, Die Nichtigkeit in Devisengesetz, 5 ZEIT. DER AkAD. F. DEUT. RECHT. 57, 58 (1938); Blau, Devisenrecht und Privatrecht, 83 JHERING'S JAIRBÜCHER 201, 224 (1933). In our own law, question has arisen whether an absolutely void transaction, in the sense of having "no legal existence for any purpose," or being a "blank piece of paper," [Cecil B. De Mille Productions v. Woolery, $61 \mathrm{~F} .2 \mathrm{~d} 45,49,53$ (C. C. A. 9th 1932) (contract violating licensing statute)] could be validated by a subsequent curative act. McLain v. Oklahoma Cotton Growers' Assn., 125 Okla. 264, 258 Pac. 269 (1927).

46. Peltzer, supra note 45, at 57, 58; GIEse \& NIEMANN, op. cit. supra note 45 at 444; Koppe-Blau, Das gesante DevisenRecht 38 (1932).

47. Giese \& NieMraNN, op. cit. supra note 45 at 444 ; Peltzer, supra note 45 , at 58 .

48. See Peltzer, supra note 45, at 58; GIESE \& NIEArann, op. cit. supra note 45, at 444. 
This rationalization not only explains the Treasury practice, but it also reflects the intention of Congress.' Senator Wagner emphasized that the freezing control .

"does not absolutely prohibit the transfers, it merely provides that the Government may investigate to determine whether the transfer was made voluntarily or under duress ....".

But this statement is, of course, to be read in conjunction with the parallel intention of preventing the passage of title by an unlicensed transaction..$^{50}$ Hence, it will not do to treat the transaction as voidable, i.e., as effective unless and until voided, for that would throw upon the Treasury the burden of ferreting out thousands of transactions for which no license application will ever be made. To accomplish the objectives of freezing control, it is necessary to conclude that no interest in blocked property can be created or transferred by an unlicensed transaction. This view preserves the freedom of the parties to negotiate and to launch "agreements," without trenching upon the efficacy of the freezing controls..$^{\text {.1 }}$

\section{InefFectiveness of JudictaI. Transfers}

There remains the reliance of the Singer case on Paragraph (4) of General Ruling No. $12,{ }^{52}$ a matter best viewed against the relation of freezing controls to transfers by judicial process. We have seen that a blocked national cannot transfer any interest in his property without a license, and that the execution of documents of transfer does not confer on the transferee any interest in the property. Can a transfer which may not be achieved by voluntary act of the parties be accomplished by resort to the courts? Preliminarily, we may also inquire, though the question has not been raised by the courts, whether the Trading with the Enemy Act was intended to authorize curtailment of traditional state judicial processes.

49. 86 CoNG. Rec. 5007 (1940). The legislative intention, of course, governs on the content to be given the "voidness.". See Harris v. Runnels, 12 How. 79, 84 (U. S. 1851).

50. See note 13 supra.

51. The theory that an unlicensed transaction is suspended and ineffective raises questions as to intervening events in the period between its physical inception and its approval by Treasury action. When licensed, does the transaction become effective $a b$ initio or as of the time the license issues? The German statute specifies effectiveness $a b$ initio, and it would seem possible to achieve the same result by Treasury regulation. What of the effect of the transaction on intervening rights? Is either party free to retreat from the contract if a license is refused? It seems unjust to hold a party to a contract for an indeterminate period, yet licenses have occasionally been granted after several denials. Similar problems are noted in the German literature. GIESE \& NiemanN, op. cit. supra note 45, at 444; KOPPE-BLAU, op. cit. supra note 46, at $39,40$.

52. 7 FED. REG. 2991 (1942). Feuchtwanger v. Central Hanover Bank [288 N. Y. 342,43 N. E.2d 434 (1944) ], also cited in the Singer case, scarcely advances the argument, for it was decided on the same day as the Singer case, and as Judge Finch remarked in a concurring opinion, the Executive Order was not in issue and there was no attempt to effect a transfer of title of the original owner. 
The first formal expression on this question is found in General Ruling No. 12 , issued on the eve of the Government's intervention as amicus curiae in the Polish Relief case. The Ruling defines "transfer" to include not only voluntary acts, but also

"the issuance, docketing, filing, or the levy of or under any judgment, decree, attachment, execution, or other judicial or administrative process or order, or the service of any garnishment." (Paragraph 5(a)).

Since General Ruling No. 12 was issued "by direction of the President," we may take this definition as a presidential construction of the term "transfer" as it appears in Section 5(b), as amended, of the Trading with the Enemy Act. ${ }^{54}$ An analogous use of the term "transfer" to conprehend attempts to pass an interest by judicial proceedings is found in the Bankruptcy Act, Section 67 of which nullifies certain "transfers", including those resulting from judicial proceedings. ${ }^{55}$ True, Section $5(\mathrm{~b})$ of the Trading with the Enemy Act does not contain the express legislative definition of "transfer" embodied in the Bankruptcy Act. And it may be thought that the need for accommodating state and federal powers suggests a more restrictive interpretation here. But an exclusion of judicial "transfers" from the impact of regulations promulgated under Section 5 (b) would invite persons denied the benefit of a voluntary transfer to resort to judicial proceedings, thereby defeating the regulatory scheme. The Singer case shows what the consequences might be. If by judicial proceedings an unlicensed assignment can be found to create a valid obligation-though temporarily unenforceable-it is highly probable that the custodian of a blocked account would decline to honor any subsequent orders respecting the account. This probability would develop into certainty if the transferee pursued his advantage through the medium of an attachment. The transferee would then have accomplished by aid of the courts a result which he could not have obtained through voluntary act; although he would still be unable to obtain full control over the property, he would have succeeded in insulating it from the control of others and in vastly, improving his chance of getting it upon the lifting of the freezing controls. Cold practicality, then, dictates the necessity of treating-as General Ruling No. 12 does-judicial transfers in the same fashion as transfers by the parties.

Nor does this interpretation require a strain on the language of the Trading with the Enemy Act. In spite of intimations from time to time that general

53. As a result of this definition of "transfer" to include every species of judicial process, any transfer of blocked property by judicial process comes within the general restrictions on transfers created by fif (1) and (2) of the Ruling, and is void unless licensed.

54. 55 Stat. 839 (1941), 50 U. S. C. ApP. \$ 616 (1946 Supp.).

55. 52 Stat. 875 (1938), 11 U. S. C. 107 (d) (1940); see $\$ 1$ (30), 52 Stat. 840 (1938), 11 U. S. C. 1 (30) (1940), defining "transfer" to include every mode "of parting with property or with an interest therein ... by or without judicial proceedings ....". 
language in federal statutes should not be construed to include action by agencies of the states, the prevailing view has been that express mention of the states is not necessary to bring their activities within the scope of federal law. ${ }^{50}$ Of course, there is no question of federal power to do so, where exemption of the states or their agencies "would undermine, if not destroy, the single control which it was one of the dominant purposes of the Congress to create." Here, too, we are faced with the possibility that the necessary single federal control may be frustrated by state action. The paramount federal power in this area is illustrated by Section $9(f)$ of the Trading with the Enemy Act, which long has immunized vested property from judicial process. ${ }^{58}$ By General Ruling No. 12 the president has directed that a similar immunity must be accorded to immobilized property. The fact that vesting is the instrument of control in the one case while blocking has been employed in the other should not spell the difference between immunity from and liability to state process. The president's determination that blocked property must not be transferred, even by judicial process, will be given great weight by the courts. ${ }^{50}$

It would hardly be necessary to stress this point were it not for Paragraph (4) of General Ruling No. 12, cited in the Singer case and mentioned earlier, which provides that an unlicensed transfer shall

\footnotetext{
"be valid and enforceable for the purpose of determining for the parties to the action or proceeding the rights and liabilities therein litigated . . . ."
}

This paragraph, it has been said, embodied the Treasury policy of considering an application for a license only on a showing "that the blocked national to be charged had consented to the transfer or that a judgment had been entered against him."'1 Apparently this policy was founded on an unarticu-

56. See Ohio v. Helvering, 292 U. S. 360,370 (1934) ; cf. New York v. United States, 326 U. S. 572 (1946).

57. University of III. v. United States, 289 U. S. 48, 59 (1933). A different question is presented where no congressional policy will be impaired by allowing the state full sway in the exercise of its admitted powers, [cf. Penn Dairies, Inc. v. Milk Control Comm'n, 318 U. S. 261, 274, 275 (1943) ], or where Congress has indicated a desire to bow to state control which was not likely to impair the federal policy. Cf. Davies Warehouse Co. v. Bowles, 321 U. S. 144, 151, 152 (1944).

58. 41 STAT. 977 (1920), 50 U. S. C. App. \$9(f) (1940). Cf. Brown v. Gerdes, 321 U. S. 178 (1944). The Court said the restrictions imposed by the Bankruptcy Act "cause any conflicting procedure in the state courts to give way." Id. at 183. See Great Northern R. R. v. Sutherland, 273 U. S. 182, 193, 194 (1927); Hicks v. Baltimore \& Ohio R. R., 10 F.2d 606, 609 (D. Md. 1926), which arose under the Trading with the Enemy Act.

59. It must not be forgotten that the federal government and especially the president are endowed with unusually broad powers in the field of international affairs. United States v. Curtiss-Wright Export Corp., 299 U. S. 304 (1936); cf. United States v. Von Clemm, 136 F.2d 968 (C. C. A. 2d 1943), cert. denied, 320 U. S. 769 (1943).

60. 7 FED. REG. 2991 (1942). The Treasury has reaffirmed that an unlicensed attachment transfers no interest. Pub. Circular No. 31, Aug. 2, 1946.

61. Reeves, supra note 1, at 45. (Reeves was with the Treasury Foreign Funds Control during 1941-1943. Editor's note to Reeves, supra note 25, at 2180). Yet the grant of a license in a case where the liability of the blocked national was in dispute need not have 
lated prejudice against what might be called "advisory licenses," a prejudice against examining license applications unless it was clear that the proposed transfers could be consummated. But this practice was a departure from the traditional preliminary administrative sifting in favor of an attempt to obtain a judicial sifting as "a condition precedent to [administrative] consideration of an application" for a license. ${ }^{62}$ The suggestion that the claimant litigate his rights before applying for a license is especially surprising because an issue which necessarily would be presented to the courts, at least implicitly, in such a proceeding would be the existence of "consideration" for the contract. Yet this is an issue as to which the Treasury Department could not abdicate its responsibility; it is abundantly clear that one of the principal functions of the licensing system was to decide whether an attempted transfer had been made under duress rather than for adequate consideration. Since as to such questions the Treasury Department could not give finality to the invited judicial proceedings, and since a judgment in any case would be only a prelude to administrative proceedings, little room was left by Paragraph (4) for more than an advisory opinion.

Somewhat belated recognition of this fact is found in the Government's brief in the Singer case:

"Of course, plaintiff conceivably may be asking this Court to enter a judgment (as-
suming it deems the facts so to warrant) in effect adjudicating that but for the
[freezing] Order the plaintiff would have been a creditor of the New York Agency
and that he can achieve that status if the Secretary of the Treasury should, in the fu-
ture, license the transaction under the Order. Since this would raise no federal ques-
tion, the United States would in that event have no interest and no objection. But
such a judgment would be merely advisory since only the Treasury's later determina-
tion could make it effective. The decisions of this Court indicate that it will not un-
dertake to enter a finding which will have 'none of the authority of a judgment"."

In arguing that the court should not enter a finding with "none of the authority of a judgment," the brief of the United States cited cases which are in point only if the Treasury Department reserved the authority to re-examine the conclusions of the court. ${ }^{64}$

been interpreted as anything more than a statement that the Treasury Department interposed no objection to the transfer. This would have left the blocked national "to be charged" free to deny liability on such non-freezing grounds as the statute of frauds, set-off, and accord and satisfaction.

62. Ibid. The Treasury Department said that it "regards the courts as the appropriate place to decide disputed claims. . . . The Treasury Department did not feel that it could finally pass on an application for a license to transfer blocked assets where the facts were disputed or liability denied." Brief for United States in the Polish Relief case, supra note 2 , p. 14.

63. See note 38 supra, at p. 28; see also the Brief for United States in the Singer case, supra note 40 , pp. 7,8 .

64. In United States v. Ferreira [13 How. 40 (U. S. 1851)], the Court dismissed for want of jurisdiction an appeal from a district judge's allowance of a claim under a statute providing that the decision on a claim should be transmitted to the Secretary of the Treas- 
Whether or not Paragraph (4) leaves the courts room for more than an advisory opinion is not in our view decisive. What should be controlling is the limiting proviso of that paragraph which the Singer case inexplicably overlooks. The proviso declares:

"[P]rovided, however, that no attachment, judgment, decree, lien, execution, garnishment, or other judicial process shall confer or create a greater right, power, or privilege with respect to, or interest in, any property in a blocked account than the owner of such property could create or confer by voluntary act prior to the issuance of an appropriate license."

Thus the invitation to the courts, expressed in Paragraph (4), to take jurisdiction of unlicensed transactions is expressly limited so as to foreclose the judicial transfer of any interest in the property unless licensed.

Since there is no serious doubt respecting the power of the president, under Section $5(\mathrm{~b})$ of the Trading with the Enemy Act, to promulgate the freezing controls, it would follow that in the absence of Paragraph (4) a court would be constrained to hold that an unlicensed transaction (including an unlicensed judicial transfer) could not transfer any interest in blocked property. Possibly this would not altogether foreclose litigation involving unlicensed transactions, but certainly little inducement would be left for any proceedings having more than peripheral contact with such transactions. The illusory relaxation embodied in Paragraph (4), which permits the transfer to be considered valid for the purpose of determining the rights of the parties, is by the express terms of the proviso so limited as to exclude a transfer of blocked property by judicial process. Paragraph (4) cannot be read in disregard of this proviso, or so as to nullify the sweeping terms of the rest of General Ruling No. 12. Even apart from the clear limitation of the proviso, Paragraph (4) should not be so read as to enable an assignee of blocked property, who has no license, to evade the impact of the freezing controls by recourse to judicial proceedings. Such a construction would plainly frustrate the executive and legislative intention.

This was the position recently taken in Markham $v$. Taylor, ${ }^{60}$ when the issue was first presented to a federal court. The claim of a state court re-

ury for payment if he was satisfied that it was just and equitable; In re Richardson [247 N. Y. $401,410,160$ N. E. 655,657 (1928) ] struck down the appointment of a New York Supreme Court justice as a prosecutor, "the delegate of the Governor in aid of an executive act, the removal of a public officer," his function being to take testimony and report his findings to the governor; In re Workman's Compensation Fund [224 N. Y. 13, 119 N. E: 1027 (1918) ] was a refusal to answer a question posed in a non-adversary proceeding, related to no pending controversy, by the State Industrial Commission, which wished advice (which might then be as freely rejected as accepted) respecting its power to adopt a resolution proposed by one of its members.

65. Paragraph (4), General Ruling No. 12, 7 FED. REG. 2991 (1942).

66. S. D. N. Y., Jan. 21, 1947. 
ceiver to "frozen" assets was denied in the absence of license on the ground that the prohibitions of the Executive Order, put beyond doubt by the express terms of Paragraph (1) and the Paragraph (4) proviso of General Ruling No. 12 , were "as applicable to a transfer by judicial process as to a transfer by voluntary act."

\section{Conclusion}

The backbone of the "freezing" program was the denial of legal effect to unauthorized transactions so far as they purport to transfer property in blocked accounts. In the Treasury's financial war on neutral speculators, a principal objective was the destruction of the hope that an assignment of frozen assets will become enforceable when freezing restrictions are abrogated. To achieve this objective, the Treasury has properly adopted the position that an unlicensed transfer creates no rights to a blocked account.

Under General Ruling No. 12, issued "by direction of the President," an unlicensed attachment is a "transfer," and accordingly it is ineffective to confer or create any rights to or interest in blocked assets. Nothing in Section 5(b), Executive Order No. 8389, or General Ruling No. 12 affords any foundation for distinguishing between the transfer of rights or interests by judicial process and the transfer of rights or interests by voluntary act of the parties. To the contrary, Section 5(b) and the Order speak only of "transactions," and in General Ruling No. 12 there is a studied effort to keep judicial process on the same level as voluntary acts so far as the transfer of rights to blocked assets is concerned. Consequently, if it be conceded that an unlicensed attachment can result in a transfer 'of rights, there is no basis in the Order or regulations under it for denying similar effect to a voluntary act.

The Polish Relief case does not hold to the contrary. It bowed to the paramountcy of federal control in this field by acknowledging that the owner of a blocked account had no power "to transfer any interest" in the account except by the Treasury's leave. There was no holding that the attachment created any interest that could not be created by voluntary act; the decision that the attachment would support jurisdiction in rem in no sense necessitates the conclusion that the attachment generated any other consequences.

The Singer case is to the contrary. But if its rationale is to be accepted, not only judicial process but also voluntary acts, though unlicensed, can effect a transfer of an interest in blocked property. This theory imperils a vital purpose of freezing controls, which was to deprive neutral speculators of the prospect that they could obtain ownership of blocked assets by outwaiting the Treasury Department. Paragraph (4), upon which the Singer case rests heavily, invited an exercise of judicial jurisdiction which courts are unable 
to undertake because they are not authorized to act as an advisory adjunct to an administrative agency, and because in the absence of license there is no effective contract and hence no cause of action to which the courts can lend enforcement. But the fact that Paragraph (4) should never have been issued does not warrant an interpretation of it which ignores the limiting proviso and threatens the entire structure of freezing controls. 